\title{
RESEARCH PAPER \\ THE INFLUENCE OF INFORMATION AND COMMUNICATION TECHNOLOGY ON GRAPHIC DESIGN: REFLECTIONS ON PEDAGOGY
}

\author{
E. Appiah ${ }^{1}$ and J. Cronjé ${ }^{2}$ \\ ${ }^{1}$ Department of Communication Design, Faculty of Art, KNUST, Kumasi \\ eddappiah@gmail.com/eappiah.art@knust.edu.gh \\ ${ }^{2}$ Faculty of Informatics and Design, Cape Peninsula University of Technology, Cape Town, South \\ Africa \\ cronjej@cput.ac.za
}

\begin{abstract}
Information and communication technologies (ICT) have influenced the teaching and learning of graphic design. The introduction of ICT has also brought in some challenges as far as the pedagogy is concerned, as it requires relearning, training and upgrading. Ironically, the pedagogy of graphic design education being championed in a university in a developing country, and seen as an adaptation of the Bauhaus theory, seems to be at variance with current practices in both the profession and in its education. This article analyses the trend of graphic design practices and how design students are using ICT, as a way of considering the paradigm shift resulting from the introduction of ICT. This is done as a way of considering the paradigm shift resulting from the introduction of ICT in the curriculum. It examines the contribution and the adaptation of Innovation Education (IE) to educational theories in the context of ICT and graphic design education. It also analyses how students undertake idea development in graphic design with ICT. The study agrees that current ICT practices call for a review of pedagogy that allows students to develop ideas digitally. It concludes by calling for an exploration of current ICT practices in graphic design education, especially in issues of ideation and pedagogy.
\end{abstract}

Keywords: ideation, pedagogy, innovation education, constructivism, graphic design

\section{INTRODUCTION}

Learning has undergone tremendous paradigm shift since the beginning of the $20^{\text {th }}$ century. Theories that have been formulated in support of teaching and learning in education, especially educational practices have and will continue to be subjected to critical reviews and changes. Some of the changes are 'mainly as a result of developments in ICT, the commercialization and globalization of education, social changes and the pursuit of quality' (Brown, 2006:109). Having realised the influence and the indispensability of ICTs, graphic design educators are supporting the teaching and learning with ICT in one way or the other. This has resulted in new ideas and possibilities in design 
86

Appiah and Cronjé

education and practices. These include online studio, as support for learning and teaching (Kvan, 2001 and Bennett, 2003); blended learning for education (Bender and Vredevoogd 2006); new courses in response to the growing needs of ICT in design education (Bender, 2005 and Ranjan, 2005); and collaborations in design projects as a result of the establishment of virtual design studios (VDS), especially in the developed economies.

Little attention is paid to graphic design pedagogy as it relates to ICT and ideation especially in developing economies. Ideation, which is the process of brainstorming with images, letters, figures and sketches, plays a critical role in coming out with a design concept. Traditionally, ideation is viewed as a paper-based activity and as ICT wades into the teaching and learning of graphic design, there seems to be deviations in the practices as students veered into the use of ICT in their ideation process. While some graphic design educators, especially in the developing economies, still hold on to the Bauhaus principles of design, which calls for identifying the processes of idea development in ideation on paper with its studio practices, students in their ideation processes seem to gain ideas on the use of ICT as they interact with technology. Anecdotal evidence indicates that some educators see these tensions as disturbing issues and a deviation of the learning outcomes of the pedagogy.

The design process and strategies for solving design problems are based on technological education, which are important. The reason being that it enhances the quality of solutions, which are real-life situations. Ideation in graphic design is geared towards finding a solution, not only to studio works, but also to reallife challenges as far as design is concerned. In education and professional practice, this is an essential part of the design process (Broadbent, in Jonson 2005). The Bauhaus principles that call for the learner to open up to issues solely from the master might not be the most appropriate educational paradigm when it comes to
ICT integration. We ask the question; with ICT integrating the ideation in graphic design and class sizes becoming larger, should educators still adopt the Bauhaus principles? How does the Bauhaus principle that seems to be of behaviourism match up with current educational paradigm of constructivism?

\section{BEHAVIOURISM VERSUS CONSTRUC- TIVISM}

Behaviourism in educational settings typifies where the teacher dominates, as in behaviour modification programmes. It also typifies situations where learning is structured by educators for students and the attention tends to fall on behaviour modification.

Behaviourism, according to Atherton (2011) is more about how learning occurs in the mind, than about how to make it happen. It is interesting when it is approached as such (Atherton, 2011). What this means is that, in the learning process of behaviourism, the mind is excluded from the learning processes. According to Jonassen (1991), the behavioural law was a primary theoretical cause of the paradigm shift in learning psychology (Jonassen, 1991). In his discussion on instructional system technology in the field of learning psychology, Jonassen debunked this assertion and explained the role of the mind as 'a material entity that controls the actions of the knower' (Jonassen, 1991:7).

Jonassen (1991) went further to attack the theory of objective reality by posing that, if our learning theory assumes that we construct meaning for objects and events by interpreting our perceptions of them in terms of our past experiences, beliefs, and biases, then each of us mentally represents our own personal reality'. By inference, there will always be differences in the way we give meaning to a situation. In graphic design, ideation can be accepted as the basis for which educators cannot prescribe a laid-down approach for learners to gain ideas to achieve their design outcomes. This is because in graphic design, every design problem may have a different approach to its solution. 
Influence of ICT on graphic design practices...

Jonassen (1991) advocates the need for objectivism and constructivism as the new philosophical paradigm for learning and education. He justifies the role of objectivism - that there is an objective reality - as what learners assimilate. And since the role of design educators is to help students learn about the real world, it is the role of the teacher or the instructor to interpret events for them (Jonassen, 1991). Juxtaposing this to constructivism, he conceded that perhaps 'what is transferred to the student is learned by the student without interpretation or reconstruction'. 'Rather than attempting to map the structure of an external reality onto learners, constructivists recommend that we help them to construct their own meaningful and conceptually functional representations of the external world'. Thus 'objectivism and constructivism represent alternative conceptions of learning and thinking, much like the artist-scientist, twoworld dialectic' (Snow, 1960 in Jonassen 1991:12). Indeed, constructivist pedagogy holds the promise of transforming the relationship between teachers and students in the direction of empowering learners to be much more active and interactive in the classroom (Means and Olson, 1997 in Wang 2009:208) .

To Wang (2009) constructivism is not new and has been the epistemological and educational paradigm within the heart of the Western world from the days of Socrates, who elicited knowledge from students by asking them carefullychosen questions (Wang 2009). Wang (2009) also attribute constructivism to Dewey whose teachings were of pragmatism. Dewey's philosophy of pragmatism lends itself to the fact that intellectual inquiry that posits reality not only through experience, but how best one should function within any given situation. Such theory of epistemology instrumentalism, is virtually the same as constructivism (Field, 2007 in Wang 2009), and is also known as pragmatism.

\section{METHODS}

With the qualitative methods of observation and content analysis of documents and artworks within the interpretive paradigm of epistemology, the study presented a case of a practical classroom setting (Creswell, 2007) in which students were given a project of branding a 'dying' company in other to produce an advertising poster introducing a new package for the company's clientele. According to Creswell (2007:73), "a case study involves the study of an issue explored through one or more cases within a bounded system (i.e., setting, a context)". Such case, according to Creswell, can be a bounded system (a case) or multiple bounded systems (cases) over time. It involves in-depth data collection of multiple sources of information through methods like observations, interviews, documents and reports. It can also report a case description and a case-bound theme (Creswell, 2007).

According to Creswell, (2007: 74), such qualitative case studies can be distinguished according to the size, "such as whether the case involves one individual, several individuals, a group, an entire programme, or an activity". Yin (2011:89) also advocates that, "if your study intends to examine specific hypotheses, you also might select a "critical" site, where the hypotheses ... can be effectively examined.

Henning (2004) in explaining qualitative inquiry of a case study quotes Merriam, one of the well-known qualitative researchers about case study (especially in education) thus:

While case studies can be quantitative and can test theory, in education they are more likely to be qualitative. A case study design is employed to gain an in-depth understanding of a situation and meaning for those involved. The interest is in process rather than variable, in discovery rather than confirmation. ... Case studies are distinguished from other types of qualitative research in that they are intensive descriptions and analyses of a single unit or bounded system ... such as an individual, a programme, event, group, intervention or community. 
In this reported case, the unit of analysis was ideation where the students were expected to develop ideas for discussions after which the best sample will be chosen for final execution. The underlying principle is that students will develop their ideas using the pencil and their sketchbooks, before finally resorting to the computer for the final execution. The primary author observed the processes in which students engaged in their lecture room/studio environments. The focus of ideation, which was the unit of analysis, was not the entire duration of the completed project. The emphasis was on the processes of developing ideas with tools, with lecturer's interactions as per the Bauhaus principles, which dovetail to the final execution of the work. There was also the focus on the use of technological tools and how lecturers were tracking the issue of ideation within the use of ICT tools (computer and design software, Wacom tablets, the internet) against the traditional graphic design practice of idea development in the sketchbooks that led to the final presentation of the design.

The participants were final year graphic design students, numbering 127 , and the rationale for using them was that they had undergone the basic fundamentals of ideation and had also done, at least six months' internship at professional design studios. According to Creswell (2007), in a qualitative study, "the researcher needs to select a site or sites to study, such as programmes, events, processes, activities, individual or several individuals". Yin (2009:11) believes that when examining contemporary events especially with relevance to behaviours that cannot be manipulated, such a case should be preferred. These students were also in transition to the professional world outside the university and therefore were neither novices nor fully professionals. The choice of a purposive sampling was not meant to generalise to a larger population but rather to gain a deeper understanding of the phenomenon (Yin, 2011; Neuman, 2007). Significantly, there was only one lecturer for this class but the unit of analysis was the understanding of the developing idea.

Data was collected through note-taking and observation of the activities (both in the studio/ lecture rooms), visual evidence of development (designs and thumbnail sketches), as well as content analysis of document - primary and secondary. These were done to enhance the rigour and analysis of the qualitative empirical data gathered and also as a verification method for data triangulation (Yin, 2011). As triangulation roles, these methods were also used as frame of mind - 'something that helps to keep your eyes and ears open for corroborating or conflicting ideas or data' (Yin, 2011:153).

\section{DISCUSSION \\ ICT and constructivism}

A major finding by observation of the processes and the designs indicate a major shift from the pencil and pen sketching to the use of ICT tools by students in the ideation stage of the conception. The size of the class made lecturers' interaction limited since students were able to create all their ideas unattended to. The introduction of ICT in design - its interactive and explorative nature - typifies the epistemology of constructivism in the educational theory. Wang (2009) in his discussions on the transformational promise of ICT for professional educators in architectural education comes out with the idea that ICTs have the potential for radically transforming educational practice. Such practices of ICT are also meant to promote the epistemology of constructivist paradigm.

Significantly, educators are rooting for learnercentred theory of learning which allows the student to gain knowledge in his discovery process, often quoted, as "students should construct their own knowledge". In graphic design and in this study, students need to make informed decisions as to the visuals and ideas that will communicate well with their thoughts. Using ICT allows students to search and apply their own creative thoughts, together with principles acquired in earlier projects. This can also help students to become active and creative 
learners, instead of mere passive and uncritical receptacles of past knowledge (Wang, 2009).

Wang (2009) bemoans the issue of pedagogy when it comes to ICT in design and questions why educators struggle to embrace technology while the necessary groundwork is not done in terms of getting enough pedagogical preparation to work with it. He accordingly poses certain questions concerning ICT implementations as far as the pedagogy is concerned. He therefore advocates the need for scholars to continue examining pedagogical issues with ICT carefully together with other issues like the cultural context of ICT. One critical area observed with ICT implementation is that of software. Our study reports that most of the software adopted by students are actually not provided by the institution but rather from students own initiative.

In her contribution to Foucault's 'Limitexperience', Thompson (2010) advocates a strong connection of learning that relates to the concept of transformation. Since learning brings a new perspective on the world to the learner, it can therefore mean change and transformation (Thompson, 2010). At any point in time, one must see a change in the learning process. This is even more significant with the introduction and use of ICT. In the reported study, students were always coming out with new ideas and usage of relevant software for developing the concepts and idea development. What used to be working yesterday, might lead to a new knowledge today, which can also change the mode of learning and teaching tomorrow. With such knowledge, learners are able to construct new ideas and meanings in their studies. Such change might cause a paradigm shift in the pedagogy. According to Wang (2009), "one of the benefits of ICT for students is its ability to transform students from being passive and uncritical receptacles into "active and creative learners, ready to take responsibility for the future" (Wang 2009:208).

Discussing ICT integration and its use in higher education, Stensaker et al., (2007) assert that "current teaching and learning schemes have, so far, not been adjusted to the technological development' as far as ICT in design education is concerned (Stensaker et al., 2007:427). The pedagogy of most of the design courses are still rooted in the Bauhaus principles of the $19^{\text {th }}$ century, even though design educators are struggling to embrace today's technology of ICT. In the reported study, and in line with studio method of graphic design education, students practice hands-on skills with the instructor observing and critiquing their work as they progress (Ellmers, 2006). Wang, (2009) believes that the hands-on, exploratory and the interactive nature of ICTs can cause students inclination toward the postmodern epistemology of constructivism as far as educational theory is concerned.

One of the arguments against the use of ICT in the ideation process of graphic design is that it eliminates the learner/educator studio interactions. From the study, the students through technology were afforded interaction. The introduction of ICT means educators will have to adopt different approaches for social interaction. These include online chats, virtual office hours, group projects and interactive software with live video and audio' (Dale, 2006:4). If ICT can make any meaningful impact in the teaching and learning of graphic design, then the pedagogy should be re-defined. In this study, some of the sketches were presented for critiquing through ICT and the lecturer was able to understand the concepts being developed by students, even though he was sceptical about some of the ideas. Such scepticism will mean educators will have to put some emphasis on interaction, flexibility and innovation with ICT in teaching and learning (Bates 2000 in Stensaker et al., 2007:431).

Making a case for the deployment of ICTs in university programmes for the education of design professionals, Wang (2011) argues for constructivism. He argues for traditional instructivist models that emphasis learning 


\section{Appiah and Cronjé}

through assimilation, regarding learning in constructivist models as the combination of converging, diverging and accommodating. All things considered, constructivism emphasis on student-centred and collaborative approach for problem solving with the teacher/professor as a coach or a facilitator, against a disseminator of knowledge. This approach seems to be well suited to the education of professionals.

\section{ICT AND EXPERIENTIAL LEARNING}

Experiential learning theory (ELT) draws on the work of prominent $20^{\text {th }}$ century scholars like John Dewey, Kurt Lewis and Jean Piget. According to Kolb and Kolb (2005), ELT proposes constructivist learning where knowledge is created and recreated in the personal knowledge of the learner. They define ELT as a situation where 'knowledge is created through the transformation of experience'. This is as a result of the combination of grasping and transforming experience. ELT also 'allows for affective changes to be recognised as learning' (Wang, 2011:191). Through experience, learners also create their own knowledge of ideas, which hitherto had not been conceived either by the learner or the teacher.

Through the observation, this study realised ICT allowed design students to gain more knowledge in their ideation process than before and thus their 'traditional idea capturing' seems to be discarded. Not only are students seeking for better ways to capture their ideas, but also the fastest way to make them real. Conceptualization from the digital point of view also means focusing on the entire spectrum of design challenges. If learning is an active process of constructing rather than acquiring knowledge, and instruction is a process of supporting that construction rather than communicating knowledge (Duffy and Cunningham, 1996), then ICT is helping students to create knowledge when they engaged with the various ICT tools in the ideation process. What seem not to be clear are what, how and where the instruction should be aligned, with the introduction of ICT. Maybe it is about time design educators and researchers consider emerging theory of 'navigationism'.

\section{NAVIGATIONISM IN THE ERA OF ICT}

A major observation from the reported study was the issue of a paradigm shift. Brown (2006) finds it difficult to comprehend why educators find it difficult to move beyond "content-driven" paradigms of constructivism. In his article "Beyond constructivism: navigationism in the knowledge era", he discusses how ICT is impacting on education and the shifts in the educational system for the past decade. Quoting Restak in his argument, Brown (2006) indicated that, "within the modern age, we must be able to rapidly process information, function amidst chaotic surroundings, always remain prepared to shift rapidly from one activity to another and redirect attention between competing tasks without losing time" (Restak as cited in Brown, 2006:109). In the current situation of changes in educational environment, educators will now have to find a way of providing preselected and carefully designed contents in their curriculum for learners (Brown, 2006:116).

Brown (2006) therefore makes a strong case for 'navigationism' as the emerging learning paradigm beyond constructivism. This new learning paradigm will mean learners "should have the ability identify, manipulate and evaluate information and knowledge, as a way of integrating such knowledge, to solve problems and also to communicate this knowledge to others" (Brown, 2006: 116). In this reported study, students were using ICT to locate the appropriate ideas within the virtual environment and studios, manipulate them for the development and execution of their desired objective as far as the design process of ideation is concerned. They might have gone through the stages in ideation using the traditional pedagogy but working within the virtual environment will make it difficult for them to trace and document these stages as required by the traditional methods of ideation.

Brown (2006) concludes in his work by exhort- 
Influence of ICT on graphic design practices...

ing design educators to focus on coaching learners to use their knowledge in their world of life "to solve problems and also to communicate this knowledge to others" (Brown, 2006:116). By this, educators would now become the source of how to navigate in the ocean of available information and knowledge. $\mathrm{He}$ therefore advocate that educators now "become coaches and mentors within the knowledge era" (Brown, 2006:116) to learners. Beyond this, educators should begin also to look at 'pedagogies that move beyond instruction to creativity, innovation and generative thinking' (Mcloughlin and Lee, 2008:647). Such generative thinking requires a paradigm that blends social software, constructivism, connectivism and navigationism (Mcloughlin and Lee, 2008). In an increasingly digital world, Mcloughlin and Lee (2008) advise that design educators will have to expand pedagogy so that learners become active participants and co- producers rather than passive consumers of content and learning processes.

Altogether, the concept of studio activity within design education is to allow for interactive participation of students and their peers to discuss and critique their works. In other words, studio teaching is seen as a "model of interaction" and for "assimilation of real-life situations". To Mcloughlin and Lee (2008), such cost of ICTs, will offer the potential for transformational shifts in teaching and learning practices, whereby learners can access peers, experts, the wider community and digital media in ways that enable reflective, self-directed learning (Mcloughlin and Lee, 2008:649).

\section{IMPLICATIONS FOR GRAPHIC DESIGN PEDAGOGY}

Analysis from the study indicates some pedagogical disturbances and imbalances, calling for a shift in paradigms. This is as a result of the introduction of ICT with ideation and ICT in graphic design education as a whole. The study painted current topology of graphic design - both in the profession and in education, ICT and the pedagogy of graphic design lead- ing to current educational paradigms that informs ICT in ideation.

The field of graphic design is much broader now than in the past and now includes disciplines such as motion graphics, environmental commodities, and new media. It has evolved from the pre-historic abstract geometric shapes to include a spectrum of ideas for film and TV and all manner of visual communication and design. It also involves understanding human engagement in an effort to create useful and pleasing artefacts.

Moreover, technology has permeated every facet of graphic design - in its teaching and learning as well as the profession. It is now almost impossible to talk about graphic design without the use of technological resources from idea development to final execution of the design solution. Computer technology has become one of the tools of idea development; in other words, a 'thinking tool'. It is also a fact that professional designers and student designers will rely very heavily upon tools and techniques to make sense of their ideation within their respective design tasks.

It can be seen that with the introduction of ICT, there seems to be pedagogical disturbances and imbalances when it comes to ideation. The graphic design profession somehow influences the pedagogy of graphic design education. Current educational pedagogy cannot fully rely on the Bauhaus principles that defined the process of design as an object-centred process, which has to produce an artefact or environment that solves a problem. Moreover, the pedagogy that includes the issue of ideation - fundamental to the design process - but still viewed in the traditional model of professional graphic design does not accommodate ICT. We need an educational paradigm that encourages cognitive learning that comes with ICT and therefore encourages the issue of pedagogy that use technology to facilitate such learning paradigms. When it comes to ICT in ideation in graphic design, educators are encouraged to adopt 
pedagogies that move beyond instruction but that which encourage creativity, innovation and generative thinking (Mcloughlin and Lee, 2008:647). Contemporary goals in education, particularly graphic design education will mean giving students required tools to stimulate the search for creative solutions to problems, as well as a solid scientific basis for decisionmaking processes (Kowaltowski, et al., 2010), especially in ideation.

Page et al., (2009) advocate that individuals must be able to adapt to novelty through an Innovation Education (IE) environment which is increasingly relevant for ideation and collaboration, based on the notion that everyone has creative ability that can be developed further through educational stimuli and selfdevelopmental activities (Page et al., 2009:11). This article supports Page et al.'s (2009) IE for the reasons that it sees possibilities in using new knowledge to produce new products and it stimulates and develops the creative abilities of students. IE also encourages the teaching, studying and learning in certain problem and innovation-based learning process; from identifying a context, where students develop their own and realization with appropriate models. Finally, it encourages and develops the students' initiative and strengthens their confidence.

\section{CONCLUSION}

ICT is encouraging graphic design students to be more innovative in their approach to design development. The argument of ICT as a tool or subject in graphic design will be settled when educators adopt the IE approach in design education. According to Page et al., (2009), creativity and problem solving are not only intrinsic to design education but also to technology education.

Pedagogically, ICT in graphic design should not be an exception especially when it comes to ideation process in design. Technological developments are also taking place in the developing countries and there is the need to also look at what is happening in the educational world of the developing economies. Going further, this article encourages research into exploring issues that will greatly help in answering questions about the methods of using ICT for the teaching and learning processes of ideation in graphic design and how effective they might be for the educator and the learner, especially in the developing world.

\section{REFERENCES}

Atherton, J. S. (2011). Learning and Teaching; Behaviourism. On-line: UK. Retrieved on August 21, 2011, from Http:// www.learningandteaching.info/learning/ behaviour.htm

Bender, D. M. (2005). Developing a Collaborative Multidisciplinary Online Design Course. Journal of Educators Online, 2(2):1-12.

Bender, D. M., and Vredevoogd, J. D. (2006). Using Online Education Technologies to Support Studio Instruction. Educational Technology and Society, 9 (4): 114-122.

Bennett, R. (2003). Proposing a framework for creative online interaction. The Omnium Project: Online.

Brown, T. H. (2006). Beyond constructivism: navigationism in the knowledge era. On the Horizon, 14 (3): $108-120$. doi:10.1108/10748120610690681

Creswell, J. W. (2007). Qualitative Inquiry and Research Design: Choosing Among Five Approaches (Second Edition); Thousand Oaks: Sage Publications. Retrieved from h t t p : / / books.google.com/books? $\mathrm{id}=$ DetLkgQeTJgC\&pgis $=1$ accessed on July 5,2011

Dale, J. S. (2006). A Technology-Based Online Design Curriculum. In Theory of Cryptography Conference, 14 - 16 April. Pp 2 - 11

Duffy, T. M., and Cunningham, D. J. (1996). 
Constructivism: Implications for the design and delivery of instructions. In Handbook of Research for Educational Communications and Technology, p. 170-198.

Ellmers, G. (2006). Reflection and Graphic Design Pedagogy: Developing a Reflective Framework to Enhance Learning in a Graphic Design Tertiary Environment Reflection and Graphic Design Pedagogy: In Australian Council of University Art and Design Schools Conference, p.1-10; Melbourne: ACUADS; 27-29 September 2006.

Henning, E. (2004). Finding your way in qualitative research (Second Edition). Pretoria: Van Schaik.

Jonassen, D. H. (1991). Objectivism versus Constructivism: Do We Need a New Philosophical Paradigm? Educational Technology Research and Development, 39 (3): 5-14.

Jonson, B. (2005). Design ideation: the conceptual sketch in the digital age. Design Studies, 26 (6):613-624.

Kolb, A. Y., and Kolb, D. A. (2005). Learning styles and learning spaces: enhancing experiential learning in the higher education. Academy of Management Learning and Education, 4 (2): 193 - 212.

Kowaltowski, D. C. C. K., Bianchi, G., and Paiva, V. T. (2010). Methods that may stimulate creativity and their use in architectural design education. International Journal of Technical Design Education, 20: 453-476.

Kvan, T. (2001). The pedagogy of virtual design studios. Automation in Construction, 10: 345-353. Retrieved from www.elsevier.com/ locate/autcon on February 14, 2011.

Mcloughlin, C., and Lee, M. J. W. (2008). Mapping the digital terrain: New media and social software as catalysts for pedagogical change. In Ascilite, p. 641-652. Retrieved on
August 2, 2001 from http:// www.ascilite.org.au/conferences/ melbourne08/proc/mcloughlin.html

Neuman, L. W. (2007). Basics of Social Research: Qualitative and Quantitative Approaches (Second Edition). New York: Pearson Educational, Inc.

Page, T., Lehtonen, M., Thorsteinsson, G., Yokoyama, E., and Ruokamo, G. (2009). A virtual learning environment in support of blended learning and distance learning in technology and design education. University of Wollongong. Retrieved August 21, 2011, from http://ir.nul.nagoya-u.ac.jp/jspai/ handle/2237/12015

Ranjan, M. P. (2005). Creating the Unknowable: Designing the Future in Education. Culture. Ahmedabad; in EAD06 Conference, April 10-12, 2005

Stensaker, B., Maassen, P., Borban, M., Oftebro, M., and Karseth, B. (2007). Use , updating and integration of ICT in higher education: Linking purpose, people and pedagogy. Higher Education, 54: 417-433.

Thompson, C. (2010). Education and/or displacement ? A pedagogical inquiry into Foucault's "limit-experience." Educational Philosophy and Theory, 42 (3): 361-377.

Wang, T. (2009). The Transformational Promise of Information and Communications Technologies ( ICTs ) for the Professional Education of Architects. Educational Technology and Society, 12 (3): 206-213.

Wang, T. (2011). Designing for Designing: Information and Communication Technologies (ICTs) and Professional Education. International Journal of Art and Design Education, 30 (2): 188-199

Yin, R. K. (2009). Case Study Research: Design and Methods (4th ed.). Los Angeles, 


\section{Appiah and Cronjé}

California: Sage Publications, Inc.

Yin, R. K. (2011). Qualitatively Research from start to finish. New York: The Guilford Press. 